\title{
ЛЕНДФОРМНИЙ ПІДХІД У ПРОЕКТУВАННІ ЯК КОНЦЕПЦІЯ СУЧАСНОСТI
}

\section{LANDFORM APPROACH AT DESIGN AS A CONCEPTION OF MODERNITY}

\author{
Новосельчук Н.Є., к.арх., доцент, Михайлова А.Б., студентка \\ (Національний університет «Полтавська політехніка імені Юрія \\ Кондратюка», м. Полтава)
}

\section{Novoselchuk N.E, Ph.D., associate professor, Mykhailova A.B., student (National University «Poltava Politechnika n.a. Yurij Kondratyuk»)}

Стійкість і збереження навколишнього середовища иляхом створення більш екологічних будівель, щзо запобігають негативному впливу, є актуальною темою для будівельників та архітекторів. У статті визначені принщипові підходи щуодо зведення об'єктів лендформної архітектури, проаналізовано особливості рельєфу, щчо виступає засобом формоутворення $і$ є найбільш стабільним компонентом ландиафту.

As for today the land form architecture at the level of design and spatial organization of an object implements the idea of interaction in the system "man - nature architecture". The land form architecture allows the architects to design building and environment, that evolves in time, complies with natural, climatic changes and customer's requirements. Such architecture opens new possibilities for interrelations between nature, man and artificial environment. Prerequisites to the land form development of architecture that resulted from global ecological problems in the world, are qualified as the ecological, economic, bioclimatic and psychological pre-conditions.

It is determined that design of buildings based on the land form approach takes place by means of land topography, that is the most stable component of landscape, determined by slopes and has a various structure. Relief is characterized by superficial and underground water, vegetation, soil. It is set that building of objects of the land form architecture is directly related to the topography of locality and the existent ecological state of territory that is its natural and climatic factors must be analyzed.

It is determined that whilst designing of the land form buildings it is possible to meet two fundamental approaches: use for object building the existent natural relief and creation of artificial relief and integration of a building in such relief basing on townplanning, composition, economic and other considerations.

Basing on the empiric experience analysis of the land form buildings, it was educed that the semideepen buildings are the most widespread, they take advantage as for creation of microclimate, insolation, wind shield, energy-savings, ecological compatibility, helio-protection, visual comfort and rational use of territory. It is 
determined that the land form architecture is characterized by visual disappearance of building and loss of traditional architectural form - facades.

Thus, the basic task of such buildings is submission of their volumes to the relief form, character individuality, integrity of perception of the object in the context of nature, and also creation of the comfort biopositive building. School of the land form architecture opens new possibilities for interrelation between nature, man and artificial environment.

Ключові слова: лендформна архітектура, ландшафт, рельєф, інтеграція.

Key words: landform architecture, landscape, relief, integration.

Вступ. В сучасній архітектурній практиці «будівництво по формі рельєфу» - це набагато більше, ніж просто формальна стратегія. Нові методи проектування, нові технології, потреба в покращенні екологічних характеристик, вибір на користь органічних підходів, екологічних матеріалів і конструкцій - викликали переосмислення традиційного відношення архітектури до землі та сприяли становленню лендформної архітектури як окремого напряму наприкінці $\mathrm{XX}$ століття. Тому для архітектора $\epsilon$ актуальними такі теми, як стійкість i збереження навколишнього середовища шляхом створення більш екологічних структур, що запобігають негативному впливу.

Аналіз відомих досліджень і публікацій. Дослідженню лендформної архітектури присвячена низка закордонних публікації вчених та практиків. Це робота S. Allen та M. McQuade «Landform Building: Architecture's New Terrain» [1], де проаналізовані лендформна будівлі таких архітекторів як T. Dean, J. Ishigami, T. Ito, T. Kimura, A.P. Kis, M. Maitzan, R. Nishizawa, C. Taylor, D. Perrault, P. Rahm та ін. Це питання розглядається також у роботах українських вчених Н.Я. Крижановської [2], I.М. Волинець [3], Я.Ю. Кузнєцової [4] та ін. Аналіз лендформної архітектури у якості різновиду екологічного напряму проводиться у дослідженнях М. Карпо [5], Р. Торен [6], П. Табб [7], Ч. Дженкс [8], Р. Дж. Корнер [9].

Практичний досвід щодо використання лендформного підходу в архітектурі проаналізовано у роботах архітекторів та архітектурних груп: M. Sorkin, K. Yeang, E. Ambasz, Sh. Endo, Fr.R.D. Hundertwasser, K. Kum, P. Eisenman та ін. MVRDV (Нідерланди), OFF Architecture (Франція), Jade + QA (Великобританія), Chartier Dalix (Франція), Bercy Chen Studio (США), Chyutin Architects (Ізраїль), Chartier-Dalix Architects (Франція), GLUCK+ (США), Bjarke Ingels Group (BIG) (США), Deca Architecture (Греція), Signum Architecture (США), Reardon Smith Architects (Великобританія), Grant Associates (Великобританія) та інші.

Метою статті $\epsilon$ визначення особливостей лендформної архітектури та рельєфу як головного формоутворюючого компоненту, встановлення основних методів формування архітектури на основі лендформного підходу. 
Постановка завдання. Визначити особливості рельєфу місцевості, що виступає головним формоутворюючим компонентом лендформної архітектури. Встановити принципові методи ऑï формування. Навести аналітичні матеріали, які необхідні для проектування лендформної будівлі.

Виклад основного матеріалу. Зв'язок людини, архітектури i природи завжди був нерозривний. На основі аналізу історичного шляху розвитку лендформної архітектури встановлено, що взаємодія споруд із землею бере свій початок від 40 тисяч років до нашої ери при створенні печер, землянок, курганів, підземного житла тощо. Ученими відмічається, що шлях до гуманізації архітектури полягає у ії звернення до природи та створенні архітектурних форм, «люблячих» свій ландшафт.

На межі XX-XXI століть зв'язок природи і архітектури стає як ніколи актуальним - архітектура набуває розвитку за екологічною парадигмою. 3'являються нові напрями: органічна, біоморфна, «зелена», «природоінтегрована», «екостійка» архітектура, лендформна архітектура та ін. Сучасні екологічні тенденції демонструють необхідність формування архітектурного простору у взаємозв'язку із природою.

Лендформний підхід в архітектурі формується на початку 1990-х pp., коли отримують розвиток теорія складності та нелінійної парадигми. У 2011 році американським теоретиком і ландшафтним архітектором Ч. Джексоном було вперше введено термін «лендформи» [8] і розглянуто таку архітектуру як нових підхід, де відбувається інтеграція природи (рельєфу) із штучним об'єктом 3 метою створення єдиної цілісної структури.

На сьогодні лендформна архітектура розглядається як напрям, який реалізує органічний підхід до формоутворення і просторової організації на основі інтеграції об'єкта із землею. Створюючи модернові прийоми формоутворення, лендформна архітектура поєднує такі галузі як містобудування, будівництво, екологія, архітектура, ландшафтний дизайн [8].

Формоутворення будівель на основі лендформного підходу відбувається за допомогою рельєфу місцевості, що показує різні варіанти взаємодії. Рельєф, що визначається нахилом, $є$ найбільш стабільним компонентом ландшафту та має різну будову - гора, пагорб, рівнина, яр, плато, котловина й ін. Рельєф також характеризують поверхневі й підземні води, рослинність, грунт. Таким чином, будівництво об'єктів лендформної архітектури прямо пов'язане із топографією місцевості, де найбільш частим $є$ використання таких типів рельєфу як пагорб, гора, рівнина. Нахил пагорбу безпосередньо впливає на характер його забудови i характеризується:

- крутизною - невеликою 15-20\%, середньою - 20-30\% та підвищеною $-30-45 \%[2]$; 
- фізичними розмірами елементарної форми рельєфу (довжина, ширина, висота над поверхнею землі, площа, яку займає);

- характером освітленості поверхні. При цьому перевагу потрібно віддавати південним, східним та західним пагорбам;

- вітровим режимом та характером впливу на поверхню пануючого вітру. Для зведення лендформних будівель доцільно віддавати перевагу пагорбу з навітряної сторони.

Необхідним $\epsilon$ проведення аналізу існуючого екологічного стану території та природно-кліматичних факторів, який включає такі аналітичні матеріали, як:

- карта геологічної будови рельєфу;

- карта форми та конфігурації рельєфу;

- карта кліматичного районування ділянки, що містить дані про інсоляцію, орієнтацію, вітровий режим та аерацію пагорбів;

- карта дефектних ділянок території за різними ознаками.

Також необхідним є розроблення заходів по мінімізації негативного антропогенного впливу, такого як захист від вітру, шуму, пилу. Проведений аналіз переваг і недоліків території проектування об'єкту лендформної архітектури дає можливість визначити формоутворюючі характеристики рельєфу.

Залежно від розташування базової площини будівлі до рівня поверхні землі або грунту та заглиблення в «тіло» ландшафту лендформні об'єкти можуть бути: 1 - наземні (наземні, розташовані базовою плошиною на поверхні землі; прибудовані до схилу; вбудовані у схил); 2 - заглиблені; 3 - підземні [11]. При цьому грунт використовується як оздоблювальний та теплоізолюючий матеріал.

На практиці найбільш розповсюдженим типом лендформних будівель $\epsilon$ напівзаглиблені, що мають переваги щодо створення мікроклімату, інсоляції, вітрозахисту, енергозбереження, екологічності, геліозахисту, а також візуального комфорту і раціонального використання території за рахунок просторового ресурсу.

При проектуванні архітектурних об'єктів на основі лендформного підходу морфотип ландшафту виступає в якості основи формоутворення. Така архітектура створюється за допомогою двох методів:

1. Наслідування природної форми рельєфу (протитипу) - при використанні природного рельєфу будівля підпорядковується йому 3 максимальним збереженням існуючої природної ситуації. Необхідно прагнути до максимального збереження рельєфу, зведення до мінімуму об'ємів зрізання та підсипання грунту та збереження рослинності (рис. 1);

2. Створення штучного рельєфу - лендформна будівля не розташовуються на ділянці проектування, а сама будує ділянку та їі новий рельєф (рис. 2). 

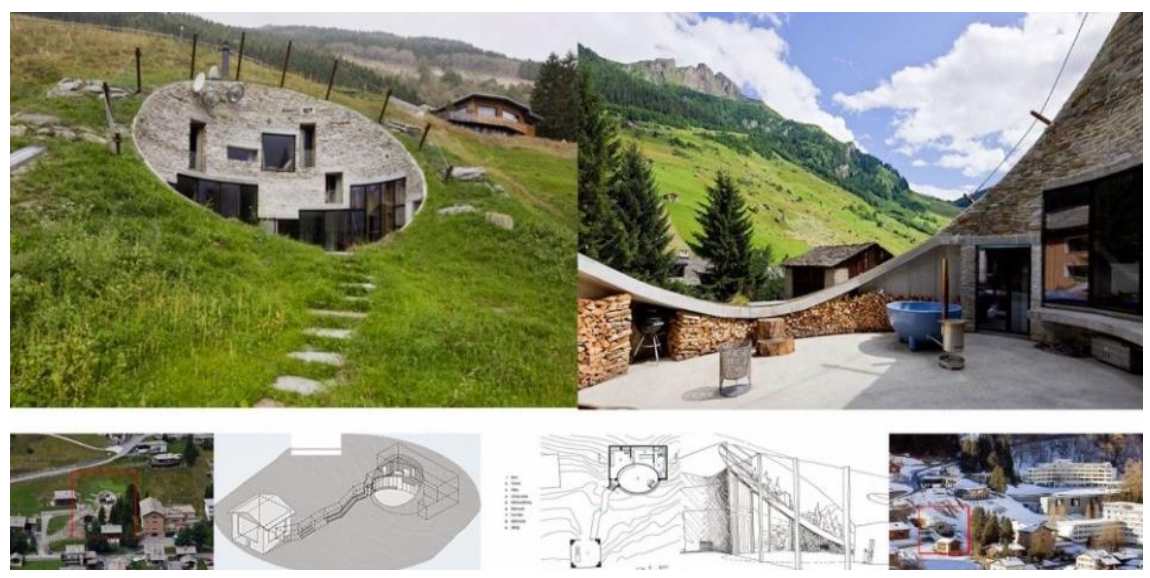

Рис. 1. Вілла Вальс, Швейцарія. Архітектори SeArch, 2009 р. [10]. Прийом візуального зникнення будівлі - абсорбція об'єкта 3 природним оточенням і його асиміляція з екологічною структурою

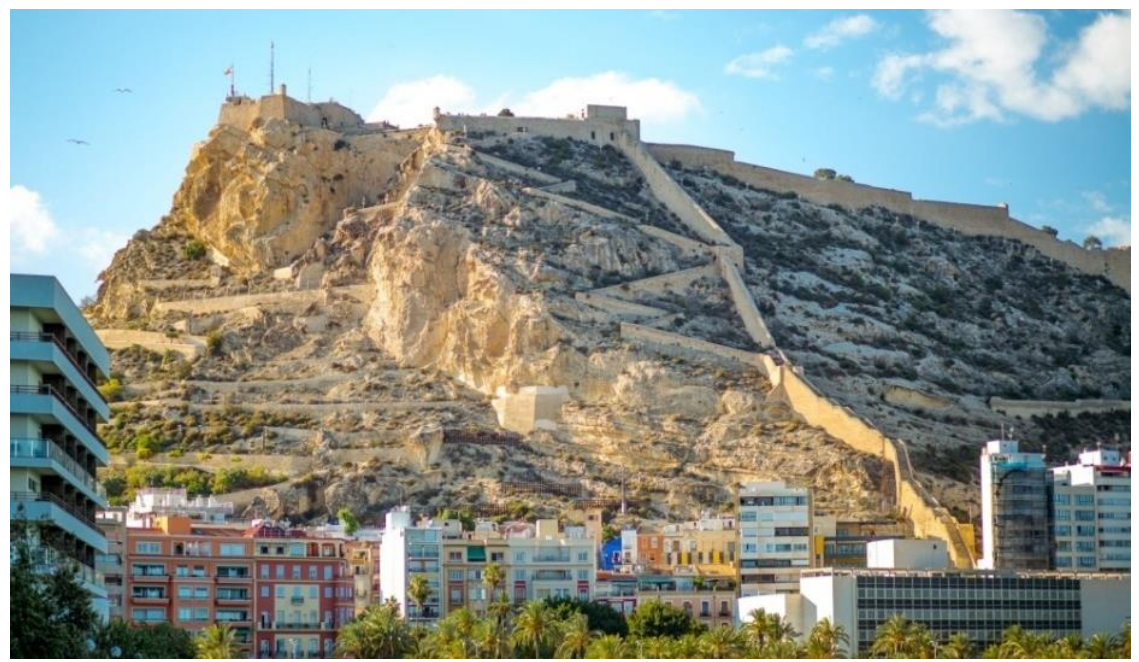

Рис. 2. Штучна гора для мультифункціонального центру у Денії поблизу Аліканте, Іспанія (В. Гуальяр, 2002 р.) [11]. Прийом терасування зведення об'єктів на пагорбах, схилах, горах та створення штучного рельєфу 
У результаті часткового або повного заглиблення будівлі в рельєф відбувається їі візуальне зникнення і втрата звичної архітектурного форми - фасадів. Отже, змінена традиційна архітектура та ізоморфізм штучної будівлі 3 природним оточенням і рельєфом $є$ характерними ознаками лендформних об'єктів.

До сучасних тенденцій формоутворення будівель на основі лендформного підходу можна виділити такі, як:

- повернення лендформної архітектури до історичних прототипів, що відображається у створенні земляних будинків-печер та будинків-нор;

- намагання зменшити візуальний вплив архітектури на ландшафт та відтворити зв'язок між природою та архітектурою;

- розташування лендформного об'єкту на ділянці проектування 3 метою формування ним генплану ділянки;

- активне використання енергозберігаючих технологій.

Висновки. Рельєф, що показує різні варіанти взаємодії із будівлею, виступає найбільш стабільним та головним формоутворюючим компонентом лендформної архітектури. При цьому найбільш характерним типом є напівзаглиблені будівлі, що мають низку переваг.

У результаті екологічної кризи в кінці XX - початку XXI століть відбувається поширення будівництва об'єктів на основі лендформного підходу. Цей підхід демонструє новітні напрями в архітектурі та є спробою зробити помітний вклад у подолання екологічної ситуації у світі.

\section{References}

1. Allen S. Landform Building : Architecture's New Terrain. Baden : SchirmerMosel, 2011. $416 \mathrm{p}$.

2. Kryzhanovskaia N. Ya., Smyrnova O. V. Henezys formyrovanyia ynnovatsyonnykh zdanyi y sooruzhenyi $\mathrm{v}$ horodskoi srede : monohrafyia. Kharkov : 2016. $189 \mathrm{~s}$.

3. Linda S.M., Volynets I.M. Teoertychnы peredumovy formuvannia lendfornykh proektiv. Suchasni problemy arkhitektury ta mistobuduvannia. K., KNUBA, 2014. Vyp. 35. S. 136-142.

4. Kuznietsova Ya.Iu. Arkhitekturne formoutvorennia pryrodointehrovanykh budivel i sporud» : dys.. ... kand. arkh. 18.00.01 Kharkiv, 2020. $200 \mathrm{s.}$

5. Carpo M. The Digital Turn in Architecture 1992-2012. Chichester : Wiley, 2013. $264 \mathrm{p}$.

6. Thoren R. Landscapes of Change : innovative designs and reinvented sites. Portland, OR : Timber Press, 2014. 264 p.

7. Tabb P. The Greening of Architecture : A Critical History and Survey of Contemporary Sustainable Architecture and Urban Design. Burlington, VT : Ashgate Pub. Co, 2013. 193 p.

8. Jencks C. The Universe in the Landscape : landforms. London : Frances Lincoln, 2011. $288 \mathrm{p}$. 
9. Corner J. The Landscape Imagination : Collected Essays of James Corner 1990 2010. New York : Princeton Architectural Press, 2014. - 320 p.

10. Est li zhyzn pod zemlej? URL: https://mypleer.com/?p=7555 (data zvernennya 02.11.2021).

11. Novoselchuk N., Shevchenko L., Kamal M.A. (2022) Ways of Integration of the Landform Architecture Buildings with Landscape. In: Onyshchenko V., Mammadova G., Sivitska S., Gasimov A. (eds) Proceedings of the 3rd International Conference on Building Innovations. ICBI 2020. Lecture Notes in Civil Engineering, vol 181, pp. 525534.

12. Guallart Architects. URL: guallart.com/projects/denia-mountain (data zvernennya 29.10.2021).

\section{Список використаної літератури}

1. Allen S. Landform Building : Architecture's New Terrain. Baden : SchirmerMosel, 2011. 416 p.

2. Крижановская Н. Я., Смирнова О. В. Генезис формирования инновационных зданий и сооружений в городской среде : монография. Харьков : 2016. 189 с.

3. Лінда С.М., Волинець I.M. Теоретичні передумови формування лендфорних проектів. Сучасні проблеми архітектури та містобудування. К., КНУБА, 2014. Вип. 35. С. 136-142.

4. Кузнєцова Я.Ю. Архітектурне формоутворення природоінтегрованих будівель і споруд» : дис.. ... канд. арх. 18.00.01 Харків, 2020. 200 с.

5. Carpo M. The Digital Turn in Architecture 1992-2012. Chichester : Wiley, 2013. 264 p.

6. Thoren R. Landscapes of Change : innovative designs and reinvented sites. Portland, OR : Timber Press, 2014. 264 p.

7. Tabb P. The Greening of Architecture : A Critical History and Survey of Contemporary Sustainable Architecture and Urban Design. Burlington, VT : Ashgate Pub. Co, 2013. 193 p.

8. Jencks C. The Universe in the Landscape : landforms. London : Frances Lincoln, 2011. 288 p.

9. Corner J. The Landscape Imagination : Collected Essays of James Corner 1990 2010. New York : Princeton Architectural Press, 2014. - 320 p.

10. Есть ли жизнь под землей? URL: https://mypleer.com/?p=7555 (дата звернення 02.11.2021).

11. Novoselchuk N., Shevchenko L., Kamal M.A. (2022) Ways of Integration of the Landform Architecture Buildings with Landscape. In: Onyshchenko V., Mammadova G., Sivitska S., Gasimov A. (eds) Proceedings of the 3rd International Conference on Building Innovations. ICBI 2020. Lecture Notes in Civil Engineering, vol 181, pp. 525534.

12. Guallart Architects. URL: guallart.com/projects/denia-mountain (дата звернення 29.10.2021). 